\begin{tabular}{c}
\hline Review of \\
ECONOMICS \\
and \\
INSTITUTIONS \\
\hline
\end{tabular}

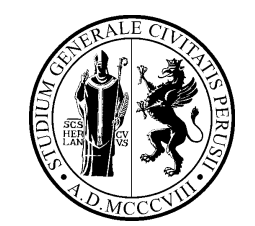

www.rei.unipg.it

\title{
The Impact of International Trade Flows on Economic Growth in Brazilian States
}

\author{
Marie Daumal ${ }^{\square}$ \\ University of Paris 8 \\ and Paris-Dauphine University
}

\author{
Selin Özyurt \\ European Central Bank \\ and University of Montpellier I
}

\begin{abstract}
This paper explores the impact of trade openness on the economic growth of Brazilian states according to their initial income level. This empirical study covers 26 Brazilian states over the period 1989-2002. Growth rates of Brazilian states are modeled as dependent on international trade flows and a set of control variables such as initial income level, human capital, private and public physical capital, growth rate of labor force and a number of interaction terms with trade openness. This empirical analysis relies on dynamic growth regressions, using the system GMM estimator. The results indicate that openness is more beneficial to states with a high level of initial per capita income and therefore contributes to increased regional disparities in Brazil. In addition, trade openness favors more industrialized states, well-endowed in human capital, rather than states whose economic activity is mainly based on agriculture. These results have important policy implications since achieving balanced territorial development has become a priority for the Brazilian federal government over the last few decades.
\end{abstract}

JEL classification: F43, R11

Keywords: international trade, growth equation, GMM estimator, Brazilian states.

We wish to thank Christophe Hurlin, Sandra Poncet, Philippe de Vreyer, Jean-Marc Siroën, Hector Guillen-Romo, Aicha Ouharon, Mehrdad Vahabi and Stefano Palombarini for their useful comments. Many thanks to the participants to the AFSE Annual Meetings (2009, France) and to those of the WRSA conference (2010, United States, Arizona).

\section{Introduction}

Regional inequalities have always been very large in Brazil: per capita GDP of the Southeast region is more than three times that of the North.

$\triangle$ Corresponding author. Address: Department of Economics, University of Paris 8, Vincennes-Saint-Denis, rue de la Liberté 2, 93526 Saint-Denis Cedex, France (Phone: +33145-444991, Fax: +33-149-407262; Email: marie.daumal@univ-paris8.fr).

\section{Recommended Citation}

Daumal, M., Özyurt, S. (2011). The Impact of International Trade Flows on Economic Growth in Brazilian States. Review of Economics and Institutions, 2(1), Article 5. doi: 10.5202/rei.v2i1.5. Retrieved from http://www.rei.unipg.it/rei/article/view/27 
There is a growing consensus among Brazilian political parties that addressing regional inequalities is a priority for the country, as they represent a risk of fragmentation. On his election in 2002, President Lula da Silva underlined that efforts to combat regional inequalities in Brazil would be one of his priorities. Brazil has undergone trade liberalization in the beginning of the 90s. A strategy of outward orientation led to reductions in tariffs and removal of other trade barriers. Brazil is now highly engaged in international trade. The purpose of this paper is to determine whether or not there is a link between Brazil's trade openness and regional inequalities inside the country. One hypothesis is that international trade might affect regional inequality through its impact on the growth of Brazilian states. International trade could be expected to reduce regional disparities if it generates greater benefits for underdeveloped regions and helps them catch up economically with leading regions. But, if Brazil's trade openness benefits the growth of richer states instead of the poorer ones, then Brazil's international trade might aggravate regional inequality. This paper aims to explore this idea.

Theoretical literature has explored the relationship between international trade and growth. Since the 1960s, the role of international trade as an "engine of growth" has been emphasized by academics (e.g., Nurkse, 1961; Krueger, 1978). International trade is expected to bring about both static and dynamic gains. Static gains from trade are closely linked to conventional trade theory (e.g., Ricardo's comparative advantages theory). According to the hypothesis of free movement of production factors across sectors, the international trade theory of Heckscher-Ohlin-Samuelson (hereafter referred to as HOS) suggests that trade openness might generate substantial gains in two major ways: by specialization in production according to country's or region's comparative advantage and by reallocation of resources between traded and non-traded sectors. Grossman and Helpman (1991) show that a country's outward orientation is likely to enhance its economic growth. Indeed international trade might constitute an effective channel for international transmission of know-how and dissemination of technological progress. In developing economies, openness to international trade could be a means of overcoming the narrowness of the domestic market and provide an outlet for surplus products in relation to domestic requirements (Myint, 1958). Furthermore, extension of market size due to export orientation is likely to bring about economies of scale in production processes (Krueger, 1978) but also in R\&D and innovative activities (Grossman and Helpman, 1991). A trading nation could improve the skills and dexterity of its labor force by learning through exporting. Exposure to new products (import of high-tech inputs), advanced organizational methods and production processes could stimulate 
technological upgrades and greater efficiency. In addition, integration in global innovation networks and international marketing contacts might provide ideas to local producers to innovate and develop new products.

However, in literature, evidence of a nexus between trade openness and economic growth is mixed and inconclusive. One theoretical argument against openness is that trade liberalization might push some economies to specialize in low value-added activities such as extraction and exploitation of natural resources and production of primary goods. Thus, in these non-dynamic sectors, low propensity for technological progress could be detrimental to long-term economic growth (Young, 1991).

Many empirical papers have explored the links between international trade and growth. The seminal empirical studies of Sachs and Warner (1995) and Frankel and Romer (1999) provide support for the growth enhancing effect of international trade. Sachs and Warner examine the impact of trade liberalization on the growth of 122 countries. Results outline that open countries exhibit higher growth rates than protectionist countries. In the same way, Frankel and Romer show that trade openness generated higher income levels in a cross section of 63 countries in 1985. Some recent studies (e.g., Dollar and Kraay, 2004; Calderon et al., 2004a) point to a significant contribution of trade openness to economic growth. They reveal that greater trade openness (which is quantified by trade volume) brings about higher growth rates. The main distinctive characteristic of these recent papers lies in the use of the Generalized Method of Moments (GMM) estimator on panel datasets. In this way, endogeneity and invariant omitted variables bias could be tackled. Generally speaking, empirical studies which rely on within-country variation mostly report robust growth benefits from trade liberalization.

Goldberg et al. (2010) show that in India input tariff liberalization (which took place in 1991) exposed local firms to a large variety of new inputs to lower prices and promoted domestic output growth. According to Wacziarg (2001)'s results, trade openness has a positive impact on economic growth: openness to trade encourages national governments to implement virtuous macroeconomic policies within the framework of international trade agreements. For instance, privatization of the state sector, better rule of law, and establishment of transparent and competitive markets could contribute to improve efficiency. In order to ensure macroeconomic stability, open economies could be more inclined to pursue inflation-preventive policies. Coe and Helpman (1995) find the empirical evidence that a country's productivity is not only dependent on its own R\&D stock but also on the R\&D stock of its trade partner. Fu (2004), who investigates the role that exports have played in China's development process, outlines that dynamic gains arising from trade orientation generally take place in the form of productivity gains. For 
instance, openness to trade could improve a country or firm's productivity through a "competition" effect. Exposure to international competition could force firms to increase efficiency (through a better allocation of existing resources, lower costs, improvements in managerial and organizational efficiency, etc.). In addition, facing global competition could motivate firms to upgrade their production process, improve quality control and move up the specialization ladder. Greater export competition could also trigger domestic R\&D and innovation efforts among local firms in order to preserve their market shares.

It should be noted that there is some criticism regarding the empirical methodology and the robustness of some aforementioned studies (Sachs and Warner, 1995; and Frankel and Romer, 1999). For instance, Rodriguez and Rodrik (2000) argue that the growth benefits of trade openness should be reconsidered using different empirical methodology. They outline that a potential two-way causality between trade and growth and the omission of relevant control variables (of high correlation with trade openness) might also generate biased results. Rodriguez and Rodrik also draw attention to the accuracy of openness indicators. In fact, these studies use "trade volume", which could be potentially correlated with economic institutions and geographic characteristics. In their empirical study, Rodrik et al. (2004) estimate the impact of institutions, geography and trade on income in a set of 140 countries, in 1995. After controlling for the quality of institutions, the results reveal no significant effect of trade on growth.

Another issue emerging from the relationship between openness and growth is that some researchers, such as Chang et al. (2009), claim that the impact of trade on growth should not be expected to be homogenous across countries. Accordingly, a growth effect due to trade openness might be conditioned by some structural characteristics and the initial income level of the economy. Chang et al. (2009) empirically test this hypothesis by creating alternative interaction variables of trade openness with respect to inflation, education, infrastructure development, governance and so on. The results reveal a positive impact of trade openness only under certain conditions. For instance, trade exerts a positive impact on per capita income only if the labor market is flexible enough. There is also an abundance of literature which provides evidence of the conditionality of openness spillovers to initial income level. Calderon et al. (2004b) detect no growth effect due to openness for countries with a low level of per capita income. In contrast, they reveal a positive growth effect of trade openness in high-income countries. Gonzales Rivas (2007) conducted a study of Mexican states. She regressed growth rates of Mexican states on Mexico's trade openness in interaction with their income level and on a set of control variables. The results show 
that trade openness benefits Mexican states with a high level of initial development more than others. It has been also asserted that, in the 1990s, China's trade openness has widened regional imbalances by draining investment and human capital from rural and inland areas to urban and coastal areas (Fu, 2004).

In lights of the aforementioned literature, one can expect trade liberalization in Brazil to widen regional disparities if we find evidence that it favors higher-income states more. The relationship between economic growth and territorial inequality relies on the following hypothesis: if rich states (or provinces) of a country experience better economic growth than poor states, then regional inequality increases in this country. On the opposite, if poor states experience better economic growth than rich states, then regional inequality decreases. The objective of this paper is to empirically investigate the mechanisms relating international trade to regional income inequalities in Brazil. Thus, this paper brings fresh empirical answers to the following questions: is there any growth enhancing effect of trade openness in the Brazilian states? Is the growth enhancing effect of openness conditioned by some structural characteristics and initial income level? Is trade openness aggravating regional imbalances in Brazil? This paper is organized as follows: Section 2 describes underlying data and empirical methodology, Section 3 presents and discusses regression results and concluding remarks are presented in Section 4.

\section{Methodology and Data}

\subsection{The Growth Equation}

To our knowledge, this study constitutes the first attempt to empirically explore the causal link between trade openness and growth in Brazilian states using a growth model and system GMM estimator. Many papers, such as Dollar and Kraay (2004) and Calderon et al. (2004a), have estimated a growth equation using the GMM estimator, but they all perform cross-country regressions on panel data (187 countries in Dollar and Kraay and 78 in Calderon et al.). The originality of this paper is to estimate the growth equation at the subnational level. It is the first time that such a study, including trade openness at the subnational level, has been done in the trade and growth literature. Indeed, subnational data such as the trade openness ratio per state and per year are necessary. Such data does not exist for most countries besides Brazil.

The empirical analysis conducted in this study is based on the GMM estimator developed for dynamic models. It covers a balanced panel dataset of 26 Brazilian states over the period 1989-2002. The methodology 
extends the conventional growth approach (e.g., Calderon et al., 2004a; Chang et al., 2009) by allowing the growth effect of openness to vary with the level of income of states. In the conventional growth literature introduced by Solow, the determinants of the growth rate, which vary across time and individuals, are the following:

$$
\ln Y_{i t}=a_{0}+\delta \ln Y_{i t-1}+\beta^{\prime} \ln X_{i t}+\lambda_{i}+\mu_{t}+\epsilon_{i t}
$$

the dependent variable is $Y_{i t}{ }^{1}$ and represents per capita GDP of state $\mathrm{i}$ at year $t$. The explanatory variables are the initial per capita GDP $Y_{i t-1}$ and a set of growth determinants that vary across time and space, defined according to the augmented Solow growth model as proposed by Mankiw et al. (1992). $\lambda_{i}$ denotes unobserved and constant individual-specific effects that might affect economic growth (e.g., geographical and political factors, quality of institutions); $\mu_{t}$ is an unobserved time-specific effect and $\epsilon_{i t}$ is the stochastic error term. The log-linear functional form is adopted in order to reduce likely heteroscedasticity.

For Brazilian states, the logarithmic regression model including an interaction term (between openness and initial level of GDP) and a set of control variables could be expressed as:

$$
\begin{aligned}
\ln Y_{i t}=a_{0}+a_{1} & \left.\ln Y_{i t-1}+a_{2} \text { lnOpenness }_{i t}+a_{3} \text { (lnOpenness }_{i t} * \ln Y_{i t-1}\right) \\
& +a_{4} \operatorname{lnPrivateCapital}_{i t}+a_{5} \ln \text { PublicCapital } \\
& +a_{6} \text { lnHumanCapital }_{i t}+a_{7} \operatorname{lnActivePopulation}_{i t}+\lambda_{i}+\mu_{t}+\epsilon_{i t}
\end{aligned}
$$

The inclusion of the state income level variable and the interaction term of

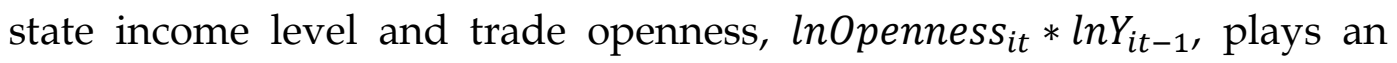
important role. The interaction term captures the effect of trade on economic growth given the level of development of the states. It determines whether or not a growth effect due to trade openness is conditioned by the initial income level of the economy and whether it benefits the growth of richer states instead of the poorer ones. The dependent variable, state GDP per capita, was obtained from the IBGE (Instituto Brasileiro de Geografia e Estatística). The series are expressed in constant prices (base 2000), in local currency (Real) and descriptive statistics are presented in Table A1 and Figure A1 in the Appendix. States' trade openness Openness ${ }_{i t}$, which is the explanatory variable of interest, is

\footnotetext{
${ }^{1}$ The dependent variable could also be the growth rate (the log difference in per capita GDP). In that case, estimated coefficients and results on the explanatory variables would be exactly the same ones. Both specifications are equivalent. Only the coefficients on the explanatory variable $\ln Y_{i t-1}$ would be different and is equal to $\delta-1$ when the dependent variable is the growth rate. In Equation 1 a positive (and $<1$ ) coefficient on $\ln Y_{i t-1}$ is a sign of convergence.
} 
quantified by the ratio of a state's trade volume (exports+imports) to its GDP. ${ }^{2}$ Exports and imports by state and by year are from the AliceWeb System maintained by the SECEX, the Foreign Trade Secretariat of the Brazilian Ministry of Development. The series are available only from 1989 and are provided in current US dollars. Figure A2 presents the trade openness ratio of each Brazilian state in 2000 and Table A2 in the Appendix shows that the degree of trade openness varies considerably across Brazilian states. For instance, in 2000, Acre's trade openness ratio is equal to $0.78 \%$ and Amazonas's trade openness ratio is equal to $45.6 \%$.

Change in active population is measured by data on growth of the workforce. The IPEA (Instituto de Pesquisa Economica Aplicada) provides data on active population (populaçao occupada) only up to 2002. We have therefore limited our study to the period 1989-2002. The variable PublicCapital $_{i t}$ corresponds to the public investment in physical capital (equipment, public real estate and construction of buildings) in percentage of the state's GDP. The series on public investment and states' GDP are provided by the Ministry of Finance of Brazil in constant local currency. For Brazil, there is no data available on private physical capital at the subnational level. We therefore used the industrial consumption of electricity as a proxy for private physical capital. More industrial equipment should imply more industrial consumption of electricity. The variable PrivateCapital $_{i t}$ is therefore the industrial consumption of electricity of a state divided by its GDP in constant currency. To control for human capital, data on average years of schooling of the population over age 25 were used. The series is based on data from the IPEA.

In Equation 2, per capita GDP of a state is thus explained by its level of GDP in the previous year (to capture the convergence effect), trade openness, private and public physical capital, human capital stock and growth of economically active population. We expect a priori growth of workforce as well as human and physical capital to exert a positive impact on growth. In order to capture any non linear impact between openness and per capita income, an interaction term (lnOpenness $\left.i t * \ln Y_{i t-1}\right)$ is included.

\subsection{The Econometric Methodology and the System GMM Estimator}

The main challenge for the estimation of this growth model is to simultaneously include all the variant determinants of growth potentially correlated to states' trade openness in order to avoid a biased estimation

\footnotetext{
${ }^{2}$ For each state and each year, we have constructed the openness ratio by dividing the exports and imports of a state by its GDP. All the series in this calculation are in current US dollars.
} 
of the coefficient on the openness variable. It should be considered that some determinants of growth, such as human capital, public and private physical capital, might affect trade performances of a state. In addition, some omitted variables that are factors of growth and potentially correlated to trade, such as geographical and political issues (e.g. location, climate, natural resources endowments, institutions and corruption) remain unchanged or change very slightly over time. In Equation 2 they are captured by the individual fixed effects $\lambda_{i}$. The time fixed effects $\mu_{t}$ control for unobserved time-specific effects and economic shocks, which are common to all Brazilian states (e.g. the period of high inflation in 1992, the Plan Real in 1994 and the economic crisis in 1999).

In recent literature, empirical issues arising from the estimation of dynamic growth models have been widely discussed (Caselli et al., 1996; Dollar and Kraay, 2004; Chang et al., 2009). They conclude that the system GMM estimator is the most suitable way to handle the problems of estimating growth equations. The empirical model (Equation 2) can be characterized as dynamic due to the presence of the lagged dependent variable (initial level of per capita GDP) as an explanatory variable. In Equation 2 the lagged dependent variable on the right-hand side is correlated by construction with the error term. Considering these, the OLS estimator should be biased and inconsistent. That is to say, it might generate unreliable parameter estimates and statistical inferences. Eliminating the fixed effects could be a solution for accurate estimation of dynamic growth models. For instance, the Within OLS estimator eliminates fixed effects by taking the first differences (Equation 3).

$$
\begin{aligned}
\ln Y_{i t}-\ln Y_{i t-1}=a_{0}+\alpha & \left(\ln Y_{i t-1}-\ln Y_{i t-2}\right)+\beta^{\prime}\left(X_{i t}-X_{i t-1}\right) \\
& +\left(\lambda_{i}-\lambda_{i}\right)+\left(\lambda_{t}-\lambda_{t-1}\right)+\left(\epsilon_{i t}-\epsilon_{i t-1}\right)
\end{aligned}
$$

But the problem is that the new error term, $\epsilon_{i t}-\epsilon_{i t-1}$, is by construction correlated with the new lagged dependent variable $\ln Y_{i t-1}-\ln Y_{i t-2}$. The Within estimator is also biased. Moreover, one of the major drawbacks of the Within estimator is to eliminate inter-individual information by taking first differences. Thus, neither the OLS estimator nor the Within estimator are completely appropriate for estimating dynamic growth regression models.

Another issue outlined by recent literature is that some determinants of growth might be endogenous to growth and could introduce two-way causality. For instance, trade openness of a state could be endogenous with respect to its economic growth. Put differently, faster growing states can be more stimulated to open up and to interact with other economies. Thus, a shock to the growth rate of a state might also affect its level of openness. 
In the recent empirical literature, the aforementioned issues have been addressed by relying on the system Generalized Method of Moments (GMM) estimator proposed by Arellano and Bover (1995) and Blundell and Bond (1998). This means that growth equations are estimated as a system of two equations: one in levels (Equation 1) and the other in first differences (Equation 3).

The GMM estimation procedure controls for and eliminates unobserved individual specific effects by first-differencing the growth equation. The system GMM estimator tackles the potential endogeneity of the explanatory variables by means of internal instruments. To address endogeneity, the system GMM relies on the lagged values of the corresponding control variables as internal instruments. In this way, it also deals with the correlation between the lagged dependent variable and the error term since the variables $\left(\ln Y_{i t-1}-\ln Y_{i t-2}\right)$ in Equation 3 and $\ln Y_{i t-1}$ in Equation 1 are now instrumented.

In the framework of the system GMM estimation, the right-hand-side variables are assumed to be endogenous, predetermined or exogenous. An endogenous variable is instrumented by its lagged values of at least two periods (or more). A predetermined variable is instrumented by its lagged values of at least one period. Thereby, in this study, we had to make some assumptions on the possible endogeneity of the control variables included in Equation 2. Accordingly, we choose to treat growth of the workforce, human capital and public physical capital as predetermined. That is to say, a shock to economic growth in period $t-1$ is expected to affect the level of active population, human capital and public capital one year later, in period $t$ and not immediately. It is justified as it is plausible that public investment is fixed for the ongoing year. But it is plausible that an economic shock influences the future investment decisions (investment in infrastructure, investment in education, etc.). Most employment contracts limit the employer's right to fire the employees immediately. In accordance with Dollar and Kraay (2004), we assume trade openness and private capital to be endogenous to economic growth. Accordingly, contemporaneous shocks to GDP growth in period t may simultaneously affect the level of trade openness and industrial energy consumption.

The GMM estimator is consistent only if the lagged values of the explanatory variables are valid instruments. In order to examine the overall validity of the instruments the Sargan test is widely used. Another specification test consists in investigating the second-order serial correlation of the residuals in first differences (Equation 3). In order to confirm adequate model specification, the first-order serial correlation should be confirmed whereas the second-order serial correlation should be rejected. The well-known issue of too many instruments in dynamic panel data GMM is dealt with in Roodman (2009). According to Roodman, 
the instrument number should not exceed $\mathrm{N}$, which is the number of individuals (26 states in this study). Otherwise, GMM becomes inconsistent and the power of the Sargan test might diminish. The solution proposed by Roodman and implemented here is to "collapse" the instrument set, instead of using all possible instruments for each available time period. In Table 1, the number of instruments is presented for each regression.

\section{Empirical Results}

\subsection{The Impact of Trade on Economic Growth}

Estimation results based on the system GMM estimates of Eq. (2) are presented in Table 1 (a correlation matrix between the explanatory variable is reported in table A3). Column 1 shows the results for the model, excluding the interaction term between income level and openness.

It can be observed that in Column 1 trade openness is related to a positive, but not significant, coefficient. That is to say, trade openness does not exert any significant effect on growth of Brazilian states. However, when the interaction term between trade and economic development is included (Column 2), we are able to detect a significant impact of openness on economic growth. It should be stated that when an interaction term has a significant coefficient it usually blurs the main effect of its constitutive terms, which are also introduced in the equation. To be more precise, in our study, in the context of interaction, it is not possible to interpret the main effect (either positive or negative) of openness. Therefore, in Column 2 the negative sign of the coefficient of openness (0.17 ) should not be interpreted as a negative effect of trade on economic growth.

In Column 2 of Table 1, the interaction term between trade openness and per capita income has a positive and significant coefficient (0.11). This reveals that the growth effect of trade openness is conditional to the level of economic development of Brazilian states. Consequently, the positive effect of trade openness declines as the level of per-capita income decreases. To be more precise, according to our calculations, the net effect of international trade on growth is positive for the states whose level of per capita income is higher than 6700 Reals (or 5450 US Dollars) in 2000 constant prices. Some poorer Brazilian states such as Piaui, Acre, Alagoas and Rio Grande do Norte are below this threshold. Therefore, trade openness might have a detrimental effect on the development of these poorer states. This might also explain the lack of significance of the trade openness variable in the model without the interaction term (Column 1). 
Moreover, this outcome is in accordance with the empirical work of Calderon et al. (2004a), which covers a panel of 78 countries over the period (1970-2000). The authors find a negative coefficient associated with the trade openness variable and a positive one associated with the interaction term between openness and income level. In addition, the study reveals no growth effect of openness for countries with low levels of per capita income. The growth effect is positive and significant for highincome countries. Gonzales Rivas (2007) conducted a similar study of Mexican states and draws the conclusion that trade openness in Mexico is more beneficial for states with higher levels of income.

Table 1 - Impact of Trade Openness on Growth of Brazilian States (GMM Estimator, 26 Brazilian states, 1989 to 2002)

\begin{tabular}{|c|c|c|c|c|c|c|c|}
\hline & \multicolumn{7}{|c|}{ Dependent Variable: $\ln Y_{i t}$, per capita income } \\
\hline & $\begin{array}{l}1) \\
\text { gmm }\end{array}$ & $\begin{array}{l}\text { (2) } \\
\text { gmm }\end{array}$ & $\begin{array}{l}\text { (3) } \\
\text { gmm }\end{array}$ & $\begin{array}{l}\text { (4) } \\
\text { fd } \\
\mathrm{gmm}\end{array}$ & $\begin{array}{l}\text { (5) } \\
\text { ols }\end{array}$ & $\begin{array}{l}\text { (6) } \\
\text { within }\end{array}$ & $\begin{array}{l}\text { (7) } \\
\text { gmm } \\
\text { span } 2\end{array}$ \\
\hline $\ln Y_{i t-1}$ & $\begin{array}{l}0.87 \\
(0.09)^{* * *}\end{array}$ & $\begin{array}{l}0.63 \\
(0.15)^{* * *}\end{array}$ & $\begin{array}{l}0.63 \\
(0.16)^{* * *}\end{array}$ & $\begin{array}{l}0.45 \\
(0.25)^{*}\end{array}$ & $\begin{array}{l}0.97 \\
(0.03)^{* * *}\end{array}$ & $\begin{array}{l}0.64 \\
(0.05)^{* * *}\end{array}$ & $\begin{array}{l}0.68 \\
(0.21)^{* * *}\end{array}$ \\
\hline $\begin{array}{l}\text { lnOpeness }_{\text {it }} \\
\text { trade in \% of GDP }\end{array}$ & $\begin{array}{l}0.03 \\
(0.09)\end{array}$ & $\begin{array}{l}-0.17 \\
(0.10)^{*}\end{array}$ & $\begin{array}{l}-0.17 \\
(0.11)^{*}\end{array}$ & $\begin{array}{l}0.10 \\
(0.14)\end{array}$ & $\begin{array}{l}0.01 \\
(0.01)\end{array}$ & $\begin{array}{l}-0.00 \\
(0.03)\end{array}$ & $\begin{array}{l}-0.15 \\
(0.09)^{*}\end{array}$ \\
\hline $\operatorname{lnOpeness}_{\text {it }} * \ln Y_{i t-1}$ & --- & $\begin{array}{l}0.11 \\
(0.06)^{* *}\end{array}$ & $\begin{array}{l}0.11 \\
(0.06)^{*}\end{array}$ & $\begin{array}{l}-0.08 \\
(0.11)\end{array}$ & $\begin{array}{l}-0.01 \\
(0.01)\end{array}$ & $\begin{array}{l}-0.01 \\
(0.02)\end{array}$ & $\begin{array}{l}0.09 \\
(0.05)^{*}\end{array}$ \\
\hline $\begin{array}{l}\text { lnHumanCapital }_{\text {it }} \\
\text { years of schooling }\end{array}$ & $\begin{array}{l}0.49 \\
(0.22)^{* *}\end{array}$ & $\begin{array}{l}0.66 \\
(0.25)^{* * *}\end{array}$ & $\begin{array}{l}0.66 \\
(0.30)^{* *}\end{array}$ & $\begin{array}{l}0.20 \\
(0.22)\end{array}$ & $\begin{array}{l}0.05 \\
(0.04)\end{array}$ & $\begin{array}{l}0.09 \\
(0.07)\end{array}$ & $\begin{array}{l}0.12 \\
(0.23)\end{array}$ \\
\hline $\begin{array}{l}\ln \text { ublicCapital } \\
\text { capital to GDP }\end{array}$ & $\begin{array}{l}0.01 \\
(0.01)\end{array}$ & $\begin{array}{l}0.00 \\
(0.03)\end{array}$ & $\begin{array}{l}0.00 \\
(0.02)\end{array}$ & $\begin{array}{l}0.02 \\
(0.22)\end{array}$ & $\begin{array}{l}-0.01 \\
(0.00)^{* *}\end{array}$ & $\begin{array}{l}0.00 \\
(0.01)\end{array}$ & $\begin{array}{l}-0.01 \\
(0.01)\end{array}$ \\
\hline $\begin{array}{l}\ln _{\text {PrivateCapital }}{ }_{\text {it }} \\
\text { capital to GDP }\end{array}$ & $\begin{array}{l}0.03 \\
(0.04)\end{array}$ & $\begin{array}{l}0.09 \\
(0.04)^{* *}\end{array}$ & $\begin{array}{l}0.10 \\
(0.05)^{* *}\end{array}$ & $\begin{array}{l}0.08 \\
(0.38)\end{array}$ & $\begin{array}{l}-0.00 \\
(0.01)\end{array}$ & $\begin{array}{l}-0.00 \\
(0.01)\end{array}$ & $\begin{array}{l}0.10 \\
(0.06)\end{array}$ \\
\hline $\begin{array}{l}\text { InActivePopulation } \\
\text { growth of workforce } \\
\text { gros }\end{array}$ & $\begin{array}{l}0.10 \\
(0.04)^{* *}\end{array}$ & $\begin{array}{l}-0.07 \\
(0.06)\end{array}$ & $\begin{array}{l}-0.03 \\
(0.16)\end{array}$ & $\begin{array}{l}0.07 \\
(0.04)^{*}\end{array}$ & $\begin{array}{l}0.03 \\
(0.04)\end{array}$ & $\begin{array}{l}0.06 \\
(0.05)\end{array}$ & $\begin{array}{l}-0.01 \\
(0.07)\end{array}$ \\
\hline constant & $\begin{array}{l}-0.45 \\
(0.21)^{* *}\end{array}$ & $\begin{array}{l}-0.33 \\
(0.34)\end{array}$ & $\begin{array}{l}-0.29 \\
(0.41)\end{array}$ & --- & $\begin{array}{l}-0.02 \\
(0.07)\end{array}$ & $\begin{array}{l}0.41 \\
(0.12)^{* * *}\end{array}$ & $\begin{array}{l}0.56 \\
(0.28)^{* *}\end{array}$ \\
\hline N. of observations & 364 & 364 & 361 & 338 & 364 & 364 & 182 \\
\hline Time dummies & yes & yes & yes & yes & yes & yes & yes \\
\hline Fixed effects & yes & yes & yes & yes & no & yes & yes \\
\hline N. of instruments & 28 & 29 & 29 & 25 & --- & --- & 24 \\
\hline $\mathrm{R}^{2}$ & -- & --- & --- & -- & 0.98 & 0.96 & -- \\
\hline Sargan test, $p$-level & 0.90 & 0.97 & 0.97 & 0.70 & --- & --- & 0.35 \\
\hline$A R(1)$ test, $p$-level & 0.00 & 0.01 & 0.00 & 0.45 & --- & --- & 0.00 \\
\hline$A R(2)$ test, $p$-level & 0.32 & 0.17 & 0.16 & 0.54 & --- & --- & 0.97 \\
\hline
\end{tabular}

Notes: Robust standard errors in parentheses: ***,** and * represent statistical significance at the $1 \%, 5 \%$ and $10 \%$ levels respectively. Column 3 shows the regression without the outliers. Column 4 shows the regression with the first-difference GMM estimator. In column 7, human capital is assumed exogenous: the $p$-values of the Sargan test are lower if human capital is assumed predetermined. 
To check the robustness of these results, in Column 3 we estimate Equation 2 without the outlier observations, thus following Hadi's methodology (1994) that detects three outlier observations. We obtain results similar to the previous estimation (column 2) for trade openness and the interaction term. The results presented in Column 4 rely on the first-difference GMM estimator and are not consistent with our previous findings. Coefficients associated with trade openness and the interaction term have the opposite signs to those in Column 2 and they are not significant. However the first-difference GMM estimator might not be efficient with the data used here, which could explain this puzzling result. Indeed, this estimator only uses the regression in difference (Equation 3) and does not exploit the Between (inter-individual data) variance of explanatory variables. Yet, the Between variance is larger than the Within (intra-individual) variance for most of the variables of Equation 2 (mainly trade openness and private capital). For instance, the Between standard deviation of the variable InOpennessit is equal to 1.05 and the Within standard deviation is lower, equal to 0.45 . Column 7 displays the system GMM estimation of the same data but based on 2 year-averages and the results are very similar to those presented in column 2 .

\subsection{Evidence of a Conditional Convergence Effect}

In Table 1 Column 2, the variable initial GDP per capita, $\ln Y_{i t-1}$, has a significant and positive coefficient whose magnitude is 0.63 . According to the empirical growth framework, this finding can be commonly interpreted as a sign of conditional convergence. This means that poorer states in Brazil tend to grow faster than richer ones. However, it should be borne in mind that Brazilian states might converge towards different levels of per capita income since, in our model, we control for structural differences between states through a set of explanatory variables. In presence of convergence, our empirical findings highlight that in Brazil greater trade openness reduces the overall convergence effect by specifically stimulating the growth of richer states. This convergence effect is significant in all regressions of Table 1.

The speed of transitional convergence, hereafter called $\mathrm{s}$, can be calculated from the coefficient $\delta$ (in Equation 1) which is associated with initial per capita income. According to the theoretical growth framework, $\delta=\exp (-\mathrm{st}), \mathrm{t}$ is the time interval between the two observations, (which is 1 here). For the convergence analysis, we chose to use the value of $\delta$ in Column 1 (model without the interaction term). Accordingly, in Column 1 $\delta$ is equal to 0.87 , which highlights that the speed of convergence equals $13 \%$. This is a relatively high rate of convergence, which implies that the distance between the initial level and the steady state level is large. Recent studies by Ferreira (2000), Azzoni (2001) and Nakabashi and Salvato 
(2007) also find evidence for economic convergence in Brazil. Ferreira (2000) examines the per capita income in Brazilian states between 1970 and 1995. He detects high rates of growth in per capita income in the poorest states during the study period and calculates the speed of convergence at $1.8 \%$. However, this rate is not really comparable to our results given that Ferreira's model does not control for structural differences across states. Our study controls for structural differences between states through the inclusion of various explanatory variables. In this way, it allows for disperse levels of steady-states across the sample. It might be possible that poorer regions converge to their steady-state in a shorter time period. If so, it is not surprising that we obtain rates of convergence speed higher than the previous literature. Azzoni (2001) also detects convergence over the period (1939-1995). He calculates the speed of absolute convergence at about $0.68 \%$ per year.

Columns 5 and 6 of Table 1 present the results of pooling (OLS) and Within (FE) estimators. Bond et al. (2001) argue that pooled and Within estimations of dynamic growth models (although they are not appropriate estimators) provide the upper and lower bands for the autoregressive parameter $\ln Y_{i t-1}$ to be consistent. In view of the results presented in Table 1 , the coefficient of the $\ln Y_{i t-1}$ variable must lie between the bands 0.64 0.97. The coefficient of 0.63 (Column 2) is just at the lower limit and can be considered as consistent.

Table 1 shows that, as expected, the proxy for human capital has a significant and positive effect on growth in regressions 1-3. This finding is also in keeping with the work of Nakabashi and Salvato (2007), which shows that disparities in human capital development also explain income disparities across Brazilian states (for the years 1970, 1980, 1991 and 2000). The coefficient related to the public capital variable is close to zero and not significant. This is quite disappointing as Brazilian states with high levels of public investment in physical capital can be expected to grow faster. However one could also consider that the fiscal burden associated with public investment or malinvestment has a detrimental effect or no effect on growth. The proxy for physical capital appears mostly with a positive and significant coefficient, thus confirming our intuitions that investment in private physical capital positively affects economic growth. In column 2 it equals 0.09. The variable "growth of workforce" is instead only significant in Column 1.

The econometric specification tests presented in Table 1 support the robustness of these results. In all GMM estimations, the Sargan test confirms the validity of chosen instruments. The serial-correlation specification tests (presented in Table 1 as AR1 and AR2) do not reject the null hypothesis of correct specification, excepted in Column 4 for the firstdifference estimation. 


\subsection{Channels Between Trade and Economic Growth in Brazilian States}

In this sub-section, we explore the mechanisms through which trade openness exerts an impact on economic growth in Brazilian states. Indeed, the most important thing now is to understand why poorer Brazilian states do not benefit, or benefit less than the other, from trade openness. The research question we explore is whether the benefits of trade openness are related to the state's endowment in human capital or its specialization pattern.

Ben-David (1999) argues that foreign trade will not transfer knowledge to countries with low levels of human capital. That is to say, the diffusion of technologies across trading economies - and thus a positive impact of trade on growth - is conditioned by their absorptive capabilities, namely their stock of human capital. Here we extend the previous specification to examine how a state's endowment in human capital could affect the relationship between trade openness and growth. We include in Equation 2 an interaction term between trade openness and human capital.

Table 2 presents alternative regressions including interaction terms. For the sake of comparison, Column 1 reports the estimation of Equation 2

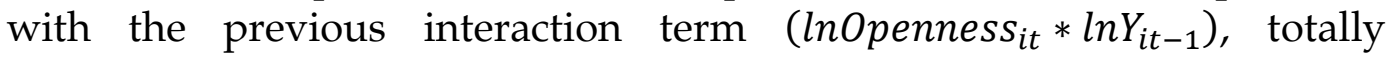
equivalent to Column 2 of Table 1. Column 2 reports the same estimation but (lnOpenness $s_{i t} * \ln Y_{i t-1}$ ) is replaced by the interaction term lnOpenness $_{i t} *$ lnHumanCapital it $_{\text {. }}$

In order to avoid high multicollinearity problems between the interaction terms (VIF values of 130 when both are included), we only include one interaction term per regression. This also simplifies the interpretation of results. It can be observed from Table 2 Column 2 that the variable lnOpeness $_{i t} *$ lnHumanCapital $_{i t}$ has a positive and significant coefficient at the 11 per cent confidence level. This result outlines that trade openness is more beneficial for states well-endowed in human capital. This confirms the importance of absorptive capabilities in order to benefit from openness.

In recent literature (Rodriguez and Rodrik, 2000 ; Chang et al. 2009) it has been asserted that trade openness might be detrimental to growth under certain conditions. As indicated in the HOS model, international trade promotes specialization and affects the level and the composition of output. However, specialization in non-dynamic sectors (such as extraction of natural resources, primary goods) implies low potential for technological upgrade of products and processes. For instance, when the initial comparative advantage lies in non-dynamic sectors, trade openness might push the economy to over-specialize in activities which do not generate long-term growth. Taking this into consideration, we can 
suppose that in Brazilian states that possess comparative advantages in low-skilled products and sectors (such as farming) there would be less scope to benefit from openness, whereas states with a minimum of industrial diversification could take advantage from trade.

Table 2 - Channels between Trade Openness and Economic Growth (GMM Estimator, 26 Brazilian States, 1989 to 2002)

\begin{tabular}{|c|c|c|c|c|}
\hline & \multicolumn{3}{|c|}{$\begin{array}{l}\text { Dependent Variable: } \\
\ln Y_{i t}, \text { per capita income }\end{array}$} & \multirow[b]{2}{*}{ (4) } \\
\hline & (1) & (2) & (3) & \\
\hline $\ln Y_{\text {it }-1}$ & $\begin{array}{l}0.63 \\
(0.15)^{* * *}\end{array}$ & $\begin{array}{l}0.82 \\
(0.10)^{* * *}\end{array}$ & $\begin{array}{l}0.91 \\
(0.09)^{* * *}\end{array}$ & $\begin{array}{l}0.91 \\
(0.10)^{* * *}\end{array}$ \\
\hline $\operatorname{lnOpenness}_{i t}$ & $\begin{array}{l}-0.17 \\
(0.10)^{*}\end{array}$ & $\begin{array}{l}-0.19 \\
(0.12)^{*}\end{array}$ & $\begin{array}{l}0.06 \\
(0.31)^{* *}\end{array}$ & $\begin{array}{l}-0.39 \\
(0.23)^{*}\end{array}$ \\
\hline lnHumanCapital $_{\text {it }}$ & $\begin{array}{l}0.66 \\
(0.25)^{* * *}\end{array}$ & $\begin{array}{l}0.45 \\
(0.24)^{*}\end{array}$ & $\begin{array}{l}0.61 \\
(0.20)^{* * *}\end{array}$ & $\begin{array}{l}0.21 \\
(0.26)\end{array}$ \\
\hline $\operatorname{lnPublicCapital}_{\mathrm{it}}$ & $\begin{array}{l}0.00 \\
(0.03)\end{array}$ & $\begin{array}{l}0.00 \\
(0.03)\end{array}$ & $\begin{array}{l}0.01 \\
(0.01)\end{array}$ & $\begin{array}{l}0.00 \\
(0.01)\end{array}$ \\
\hline lnPrivateCapital $_{\text {it }}$ & $\begin{array}{l}0.09 \\
(0.04)^{* *}\end{array}$ & $\begin{array}{l}0.07 \\
(0.03)^{* *}\end{array}$ & $\begin{array}{l}0.04 \\
(0.03)\end{array}$ & $\begin{array}{l}-0.00 \\
(0.05)\end{array}$ \\
\hline $\operatorname{lnActivePopulation~}_{\text {it }}$ & $\begin{array}{l}0.07 \\
(0.06)\end{array}$ & $\begin{array}{l}0.09 \\
(0.06)\end{array}$ & $\begin{array}{l}0.06 \\
(0.05)\end{array}$ & $\begin{array}{l}0.04 \\
(0.03)\end{array}$ \\
\hline $\begin{array}{l}\text { InAgriculturalsector } \\
\text { (in \% of GDP) }\end{array}$ & --- & --- & $\begin{array}{l}0.06 \\
(0.03)^{* *}\end{array}$ & --- \\
\hline $\begin{array}{l}\text { InIndustrialsector }_{i t} \\
\text { (in \% of GDP) }\end{array}$ & --- & --- & --- & $\begin{array}{l}-0.27 \\
(0.16)^{*}\end{array}$ \\
\hline \multicolumn{5}{|l|}{ Interaction terms: } \\
\hline $\operatorname{lnOpenness}_{\mathrm{it}} * \ln \mathrm{Y}_{\mathrm{it}-1}$ & $\begin{array}{l}0.11 \\
(0.06)^{* *}\end{array}$ & --- & --- & --- \\
\hline $\operatorname{lnOpenness}_{i t} * \operatorname{lnHumanCapital}_{\mathrm{it}}$ & --- & $\begin{array}{l}0.11 \\
(0.07)^{*}\end{array}$ & --- & --- \\
\hline $\operatorname{lnOpenness}_{\text {it }} * \ln$ Agriculturalsector ${ }_{\text {it }}$ & --- & --- & $\begin{array}{l}-0.02 \\
(0.01)^{*}\end{array}$ & --- \\
\hline $\operatorname{lnOpenness}_{\mathrm{it}} * \operatorname{lnIndustrialsector} \mathrm{r}_{\mathrm{it}}$ & --- & --- & --- & $\begin{array}{l}0.15 \\
(0.09)^{*}\end{array}$ \\
\hline constant & $\begin{array}{l}-0.33 \\
(0.34)\end{array}$ & $\begin{array}{l}-0.30 \\
(0.33)\end{array}$ & $\begin{array}{l}-0.99 \\
(0.31)^{* * *}\end{array}$ & $\begin{array}{l}0.33 \\
(0.65)\end{array}$ \\
\hline N. of observations & 364 & 364 & 364 & 364 \\
\hline Time dummies & yes & yes & yes & yes \\
\hline Fixed effects & yes & yes & yes & yes \\
\hline N. of instruments & 28 & 30 & 30 & 31 \\
\hline Sargan test, p-level & 0.97 & 0.99 & 0.85 & 0.92 \\
\hline$A R(1)$ test, $p$-level & 0.00 & 0.00 & 0.00 & 0.00 \\
\hline AR(2) test, $p$-level & 0.17 & 0.21 & 0.51 & 0.96 \\
\hline
\end{tabular}

Notes: Robust standard errors in parentheses: ${ }^{* * *},{ }^{* *}$ and * represent statistical significance at the $1 \%, 5 \%$ and $10 \%$ levels respectively. The Sargan test confirms the validity of the set of instruments. 
Before liberalization of Brazilian trade, states had different specialization patterns and thus different comparative advantages. The rich Southeast was already specialized in manufacturing products. In the Northeast and Amazonian regions (with the exception of Amazonas), economic activity was mainly driven by the production of sugar, cacao, cotton, mining and exploitation of natural-resources. Table A4 presents the share of the industrial sector in GDP in 1989 and 2002 for each Brazilian state. The industrialized states are the same in 1989 as in 2002. They include Amazonas (thanks of the Free Trade Zone in Manaus) followed by São Paulo, Paraná, Sergipe, Santa Catarina, Rio de Janeiro, all of them in the South and Southeast Regions, with the exception of Amazonas. In the state of São Paulo, in 1989, agriculture represented 4\% of GDP, whereas the industrial sector accounted for 54\%. In the Northern state of Maranhão, agriculture represented 27\% of GDP and the industrial sector only $19 \%$. Therefore, we can expect that openness to international markets wouldn't produce the same effect on all of the states.

On the one hand, it can promote knowledge-intensive and high-valueadded activities in the industrialized states, while, on the other hand, it can confine some regions specialized excessively in non-dynamic sectors. Here we examine whether the impact of trade openness on growth could be conditioned by the specialization pattern of Brazilian states. To this end, we introduced two new interaction terms in Table 2, namely the variable Agriculturalsectorit, which corresponds to the ratio of agriculture to GDP (in log) and can be considered as a proxy of comparative advantage in agricultural sectors.

The variable Industrialsector it is the ratio of the secondary sector to GDP (in $\log$ ). We can remark from Table 2 Column 3 that the coefficient associated with the interaction term between openness and agricultural sector intensity is negative (-0.02). This confirms the detrimental effect of trade openness in primary-sector driven economies. According to our calculations trade openness has a negative effect on growth in states where the agricultural sector accounts for more than $20 \%$ of GDP on average over the period 1989-2002. In contrast, in Column 4, it can be noticed that the coefficient of the interaction term between openness and industrial sector intensity is positive $(0.15)$ and significant. This indicates that openness benefits states specializing in industrial activities more. We found that openness exerts a growth enhancing effect in states whose industrial sectors accounts for more than 14\% of GDP. It should be noted that the correlation between industrial sector and per capita GDP is low, equal to +0.12 , as presented in Table A5. 


\subsection{A Case Study: the State of Maranhão}

In order to illustrate these findings, we now focus our analysis on a case study. We chose the state of Maranhão, located in the Northern region, because Maranhão is the poorest Brazilian state and, at the same time, one of the most open to foreign trade, as shown in Figure A3. The main activities of the state are mining and metallurgical production, the production of iron and aluminium as well as agriculture including the production of soybeans, silviculture, forestry and logging, cattle-farming, fishing and crops. Production patterns are almost equivalent in 1989 and 2002. In 1989, agriculture represented $27 \%$ of GDP (14\% in 2002) and the industrial sector, which includes mining and metallurgical production, only $19 \%$ (15\% in 2002). It is one of the least industrialized states in Brazil.

Table 3 presents some data on Maranhão over the period 1989-2002: GDP per capita, exports and imports in percentage of GDP. We observe that income per capita has changed little over the period, whereas its exposure to international trade has increased significantly from 1989 to 2002. The trade openness ratio was $15.1 \%$ in 1989 and $38.7 \%$ in 2002. The first observation is that Maranhão - poor and open - has probably not benefited from greater trade openness.

Table 3 - Case Study: the State of Maranhão. Trade Openness Ratio and GDP Per Capita

\begin{tabular}{cccc}
\hline \hline Year & $\begin{array}{c}\text { GDP per capita } \\
\text { (in constant Real) }\end{array}$ & $\begin{array}{c}\text { Export } \\
\text { in of GDP }\end{array}$ & $\begin{array}{c}\text { Import } \\
\text { in of GDP }\end{array}$ \\
\hline 1989 & 1520 & 12.8 & 2.3 \\
1990 & 1369 & 12.0 & 2.7 \\
1991 & 1384 & 14.3 & 6.7 \\
1992 & 1346 & 13.6 & 4.7 \\
1993 & 1348 & 13.5 & 4.8 \\
1994 & 1479 & 12.9 & 3.9 \\
1995 & 1454 & 12.2 & 3.6 \\
1996 & 1660 & 10.0 & 6.0 \\
1997 & 1632 & 11.0 & 6.0 \\
1998 & 1498 & 10.3 & 5.0 \\
\hline 1999 & 1527 & 15.2 & 8.4 \\
\hline 2000 & 1615 & 15.1 & 9.7 \\
\hline \hline
\end{tabular}

Maranhão's greater exposure to trade comes from an increase in imports. Considering the trade effect on growth, importing a lot is not a problem in itself since the literature argues that the positive effects from foreign trade also come from imports such as high-tech inputs, cheaper inputs and a new variety of inputs. For a trading state, the pattern of its imports might affect its level of productivity and economic growth. For instance, import of high technology capital-intensive and intermediate 
goods could raise productivity and encourage innovation in local production.

SECEX provides the annual composition of international trade of Brazilian states. In 1989, Maranhão imported mineral fuel, petroleum derivatives and oil (the three represent $50 \%$ of total imports), boats (30\% of imports) and some metallurgical bauxite ( $2 \%)$ and coal (2\%). After Brazil's trade liberalization, Maranhão imported much more: the value of the imports increased from 84 million in 1989 to 868 million in 2002, in current dollars. However, although imports have changed in terms of quantity, they have not changed in quality. In 2002, Maranhão still imports mineral fuels and oils (88\% of imports) and some engines and machine tools (8\%). But since there are no details on the engines and machine tools, we cannot know whether they contain high technology. Anyway, we see the poor variety of imports, destined to feed mining and metallurgy and agricultural production. We do not see how these imports could be beneficial for economic growth, given that they are used to support the local industry in a non-dynamic sector.

Trade liberalization may encourage technological upgrades and prompt a trading state to move gradually up the comparative advantage ladder. It can progressively shift its production from low-skilled primary or manufacturing goods to higher value-added capital intensive goods, which can sustain long-term growth. A shift in the composition of a state's exports would be a sign of change in economic specialization. In 1989 Maranhão exported aluminium ( $84 \%$ of total of exports), basic chemical products $(11 \%)$ and iron $(4 \%)$. In 2002, its exports were almost the same with aluminium (50\% of the total), iron (24\%), chemical products $(11 \%)$ and fruits (12\%). The idea behind this description is that Maranhão's trade openness hasn't changed anything in its specialization and production structure. Or worse, openness may have pushed the state to become even more specialized in these non-dynamic sectors.

Maranhão does not benefit from imported technological progress because the state does not import high-tech goods and it does not really benefit from exports because exporting does not induce a shift from low value-added primary goods to higher value-added capital intensive goods. Actually, in view of Maranhão's experience, the important question does not seem to be "to be open or not to be open" but rather: (i) What is the production pattern of the state just before trade liberalization ? (ii) Will this production pattern benefit from trade openness ? and (iii) What kind of products does it trade with its foreign partners? The answers to these questions could partly allow us to determine whether trade openness is likely to have a positive effect on the economic growth of a trading state. 


\section{Conclusions}

In this study the relationship between trade openness in Brazilian states, economic growth and regional imbalances is investigated. For this purpose, we ran several non-linear growth regressions, relying on the system GMM estimator. Econometric results show that in Brazil the growth effect of trade openness is conditioned by the level of initial income. That is to say, trade openness encourages the growth of richer states more than poorer ones, therefore contributing to widening regional inequalities and offsetting the convergence effect across states. All else equal, empirical results also show that trade openness is likely to benefit industrialized states and those more endowed in human capital. The analysis of these findings and the case study of Maranhão suggest that "to be open" is not enough to enhance economic growth in a state. The question concerns more "how and in which way" the state is open. Analyzing the composition of imports and exports of a state over a given period can help determine whether a state benefits or not from trade openness. For instance, imports of high-tech inputs and imports of raw materials probably do not have the same impact on the productivity and economic growth of a state.

The other main finding of this study concerns evidence of a convergence effect in Brazil. However, according to our calculations, Brazilian states converge towards different levels of development and high regional disparities should persist in the future. This finding has serious policy implications considering that achieving balanced territorial development has become a priority for the Brazilian federal government over the last few decades. Up until now, Brazil has been unable to reduce inequalities between rich and poor states, under-developed states. Furthermore, Brazil's embrace of globalization may be an additional factor of regional inequality. A policy space is certainly needed to ensure a better territorial balance within the country. The Accelerated Growth Program of President Lula da Silva should help to reduce the marginalization of Amazonian and Northern states as one of its priorities is to increase private and public investment in transport infrastructure. However, active policies promoting zones of economic development in the poorest regions could be a solution. Indeed, for political reasons, the Brazilian government created the Manaus Free Trade Zone in 1967 in the state of Amazonas, which has been an economic success. Amazonas is now one of the richest states in Brazil. More active government policies at the Federal level could enhance economic development in other states. 


\section{References}

Arellano, M., \& Bover, O. (1995). Another Look at the Instrumental-Variable Estimation of Error-Components Models. Journal of Econometrics, 68(1), 29-51. doi:10.1016/0304-4076(94)01642-D

Azzoni, C.R. (2001). Economic Growth and Regional Income Inequality in Brazil. Annals of Regional Science, 35(1), 133-152. doi:10.1007/s001680000038

Ben-David, D. (1999). Teach your Children Well: Planting the Seeds of Education and Harvesting the Benefits of Trade. Paper 2000-5, Tel-Aviv University.

Blundell, R., \& Bond, S. (1998). Initial Conditions and Moment Restrictions in Dynamic Panel Data Models. Journal of Econometrics, 87(1), 115-143. doi:10.1016/S0304-4076(98)00009-8

Bond, S., Hoeffler, A., \& Temple, J. (2001). GMM Estimation of Empirical Growth Models. Economics Papers 2001-W21, Economics Group, Nuffield College, University of Oxford.

Calderon, C., Fajnzylber, P., \& Loayza, N. (2004a). Economic Growth in Latin America and The Caribbean: Stylized Facts, Explanations, and Forecasts. Working Papers Central Bank of Chile 265, Central Bank of Chile.

Calderon, C., Loayza, N., \& Schmidt-Hebbel, K. (2004b). External Conditions and Growth Performance. Working Papers Central Bank of Chile 292, Central Bank of Chile.

Caselli, F., Esquivel, G., \& Lefort, F. (1996). Reopening the Convergence Debate: A New Look at Cross-country Growth Empirics. Journal of Economic Growth, 1(3), 363-89. doi:10.1007/BF00141044

Chang, R., Kaltani, L., \& Loayza, N. (2009). Openness can be Good for Growth: The Role of Policy Complementarities. Journal of Development Economics, 90(1), 33-49. doi:10.1016/j.jdeveco.2008.06.011

Coe, D.T., \& Helpman, E. (1995). International R\&D Spillovers. European Economic Review, 39 (5), 859-887. doi:10.1016/0014-2921(94)00100-E

Dollar, D., \& Kraay, A. (2004). Trade, Growth and Poverty. The Economic Journal, 114(493), 22-49. doi:10.1111/j.0013-0133.2004.00186.x

Ferreira, A. (2000). Convergence in Brazil: Recent Trends and Long-run Prospects. Applied Economics 32(4), 479-489. doi:10.1080/000368400322642

Frankel, J., \& Romer, D. (1999). Does Trade Cause Growth ?. American Economic Review, 89(3), 379-399. doi:10.1257/aer.89.3.379

$\mathrm{Fu}, \mathrm{X}$. (2004). Exports, Foreign Direct Investment and Economic Development in China. London and New York: MacMillan, Palgrave McMillan. doi:10.1057/9780230514836

Goldberg, P., Khandelwal, A., Pavcnik, N., \& Topalova, P. (2010). Imported Intermediated Inputs and Domestic Product Growth: Evidence from India. The Quarterly Journal of Economics, 125(4), 1727-1767. doi:10.1162/qjec.2010.125.4.1727 
Gonzales Rivas, M. (2007). The Effect of Trade Openness on Regional Inequality in Mexico. The Annals of Regional Science, 41(3), 545-561. doi:10.1007/s00168006-0099-x

Grossman, G., \& Helpman, E. (1991). Trade, Knowledge Spillovers, and Growth. European Economic Review, 35(2), 517-526. doi:10.1016/0014-2921(91)90153-A

Hadi, A. S. (1994). A Modification of a Method for the Detection of Outliers in Multivariate Samples. Journal of the Royal Statistics Society, 56(2), 393-396.

Krueger, A.O. (1978). Foreign Trade Regimes and Economic Development: Liberalization Attempts and Consequences. Cambridge, MA: Ballinger for the NBER.

Mankiw, G., Romer, P., \& Weil, D. (1992). A Contribution to the Empirics of Economic Growth. Quarterly Journal of Economics, 107(2), 407-437. doi: $10.2307 / 2118477$

Myinth, H. (1958). The Classical Theory of International Trade and the Underdeveloped Countries. Economic Journal, 68(270), 317-337.

Nakabashi, L., \& Salvato, M.A. (2007). Human Capital Quality in the Brazilian States. Revista Economia, 8, 211-222.

Nurkse, R. (1961). Patterns of Trade and Development, Wicksell Lectures. Oxford: Basil Blackwell.

Rodríguez, F., \& Rodrik, D. (2000). Trade Policy and Economic Growth: A Skeptics Guide to the Cross-National Evidence. In Bernanke, B., \& Rogoff, K. (Eds.). NBER Macroeconomics Annual 15, MIT Press.

Rodrik, D., Subramanian, A., \& Trebbi, F. (2004). Institutions Rule: the Primacy of Institutions over Geography and Integration in Economic Development. Journal of economic growth, 9(2), 131-165

Roodman, D. (2009). A Note on the Theme of Too Many Instruments. Oxford Bulletin of Economics and Statistics, 71(1), 135-158. doi:10.1111/j.14680084.2008.00542.x

Sachs, J.D., \& Warner, A.M. (1995). Economic Reform and the Process of Global Integration. Brookings Papers on Economic Activity, 1995(1), 1-118. doi: $10.2307 / 2534573$

Wacziarg, R. (2001). Measuring the Dynamic Gains from Trade. The World Bank Economic Review, 15(3), 393-429. doi:10.1093/wber/15.3.393

Young, A. (1991). Learning by Doing and the Dynamics Effects of International Trade. Quraterly Journal of Economics, 106(2), 369-405. 


\section{Appendix}

Table A1 - Statistics on GDP per Capita (in Brazilian Real Constant) of Brazilian States in 1989 and 2002.

\begin{tabular}{lcccc}
\hline & Mean & Standard Error & Min & Max \\
\hline Year 2002 & 5287 & 2850 & 1646 & 13822 \\
Year 1989 & 5081 & 2713 & 1390 & 11580 \\
\hline \hline
\end{tabular}

Source: Instituto Brasileiro de Geografia e Estatística

Table A2 - Statistics on the Trade Openness Ratio [(Exports+Imports)/GDP) of Brazilian States in 1989 and 2002.

\begin{tabular}{lcccc}
\hline & Mean & Standard Error & Min & Max \\
\hline Year 2002 & $18 \%$ & 14 & $0.96 \%$ & $54 \%$ \\
Year 1989 & $7.7 \%$ & 6.82 & $0.04 \%$ & $29 \%$ \\
\hline \hline
\end{tabular}

Notes: In 2002, the most closed state in terms of international trade has a trade openness ratio of $0.96 \%$ and the most open state has a ratio of $54 \%$. Mean is the mean of all trade openness ratios of the Brazilian states (not weighted by their GDP).

Table A3 - Correlation Matrix between Explanatory Variables of Growth in Equation 2 and Table 1.

\begin{tabular}{|c|c|c|c|c|c|c|c|}
\hline & $\ln Y_{i t-1}$ & InOpenness & InOpenness $* \ln Y_{i t}$ & InhumanK & Inpublick & InprivateK & $\begin{array}{l}\text { Lngrowth } \\
\text { workforce }\end{array}$ \\
\hline $\ln Y_{i t-1}$ & 1.00 & --- & --- & --- & --- & --- & --- \\
\hline InOpenness & 0.28 & 1.00 & --- & --- & --- & --- & --- \\
\hline InOpenness $* \ln Y_{\mathrm{it}-1}$ & 0.68 & 0.85 & 1.00 & --- & --- & --- & --- \\
\hline InhumanK & 0.76 & -0.00 & 0.37 & 1.00 & --- & --- & --- \\
\hline Inpublick & -0.24 & -0.24 & -0.30 & 0.09 & 1.00 & --- & --- \\
\hline InprivateK & -0.10 & 0.68 & 0.39 & -0.39 & -0.26 & 1.00 & --- \\
\hline $\begin{array}{l}\text { Lngrowth } \\
\text { workforce }\end{array}$ & -0.02 & -0.06 & -0.05 & 0.03 & 0.06 & -0.08 & 1.00 \\
\hline
\end{tabular}

Notes: K stands for capital. 
Table A4 - Industrial Sector in Percentage of GDP by Brazilian States in 1989 and 2002

\begin{tabular}{|c|c|c|c|c|}
\hline State & $\begin{array}{l}\text { Industrial sector } \\
\text { in } 1989\end{array}$ & $\begin{array}{l}\text { Industrial sector } \\
\text { in } 2002\end{array}$ & Rank in 1989 & Rank in 2002 \\
\hline Amazonas & 64.13 & 36.86 & 1 & 1 \\
\hline São Paulo & 54.52 & 25.33 & 2 & 7 \\
\hline Paranà & 47.24 & 25.35 & 3 & 6 \\
\hline Sergipe & 46.92 & 28.51 & 4 & 3 \\
\hline Santa Catarina & 46.76 & 29.33 & 5 & 2 \\
\hline Rio de Janeiro & 46.26 & 20.89 & 6 & 15 \\
\hline Rio Grande Do Sul & 44.55 & 24.40 & 7 & 10 \\
\hline Minas Gerais & 43.44 & 24.81 & 8 & 9 \\
\hline Pernambuco & 42.58 & 18.80 & 9 & 17 \\
\hline Cearà & 42.57 & 19.92 & 10 & 16 \\
\hline Espírito Santo & 39.94 & 26.32 & 11 & 5 \\
\hline Bahia & 36.57 & 25.01 & 12 & 8 \\
\hline Rio Grande do Norte & 34.44 & 22.06 & 13 & 12 \\
\hline Parà & 28.38 & 21.16 & 14 & 4 \\
\hline Goiás & 28.19 & 21.16 & 15 & 13 \\
\hline Piauí & 25.95 & 13.79 & 16 & 21 \\
\hline Paraíba & 25.01 & 21.14 & 17 & 14 \\
\hline Alagoas & 24.19 & 23.45 & 18 & 11 \\
\hline Rondônia & 21.41 & 12.44 & 19 & 22 \\
\hline Acre & 20.90 & 9.74 & 20 & 25 \\
\hline Mato Grosso do Sul & 20.19 & 14.77 & 21 & 20 \\
\hline Maranhão & 19.64 & 15.31 & 22 & 18 \\
\hline Mato Grosso & 17.18 & 15.23 & 23 & 19 \\
\hline Roraima & 11.06 & 11.01 & 24 & 24 \\
\hline Distrito Federal & 10.71 & 5.32 & 25 & 26 \\
\hline Amapá & 7.58 & 12.09 & 26 & 23 \\
\hline
\end{tabular}

Sources: IPEA and calculation by the authors. In this table, the industrial sector represents $64.13 \%$ of GDP for the state of Amazonas in 1989 and 36.86\% in 2002. It was the most industrialized state in Brazil in 1989 (rank 1) but also in 2002 (rank 1).

Table A5-Correlation Matrix between Per Capita Income, Human Capital and Economic Sectors (Variables of Regression in Table 2)

\begin{tabular}{|c|c|c|c|c|}
\hline & $\ln Y_{\text {it-1 }}$ & InHumancapital $_{\text {it }}$ & InAgriculturalsector $_{i t}$ & InIndustrialsector $_{\text {it }}$ \\
\hline $\ln Y_{i t-1}$ & 1.00 & --- & --- & --- \\
\hline InHumancapital $_{\text {it }}$ & 0.76 & 1.00 & --- & --- \\
\hline InAgriculturalsector ${ }_{i t}$ & -0.44 & -0.53 & 1.00 & --- \\
\hline InIndustrialsector ${ }_{i t}$ & 0.12 & -0.53 & 0.16 & 1.00 \\
\hline
\end{tabular}


Figure A1 - Regional Inequality in Brazil. Per Capita Income of Brazilian States in 2000

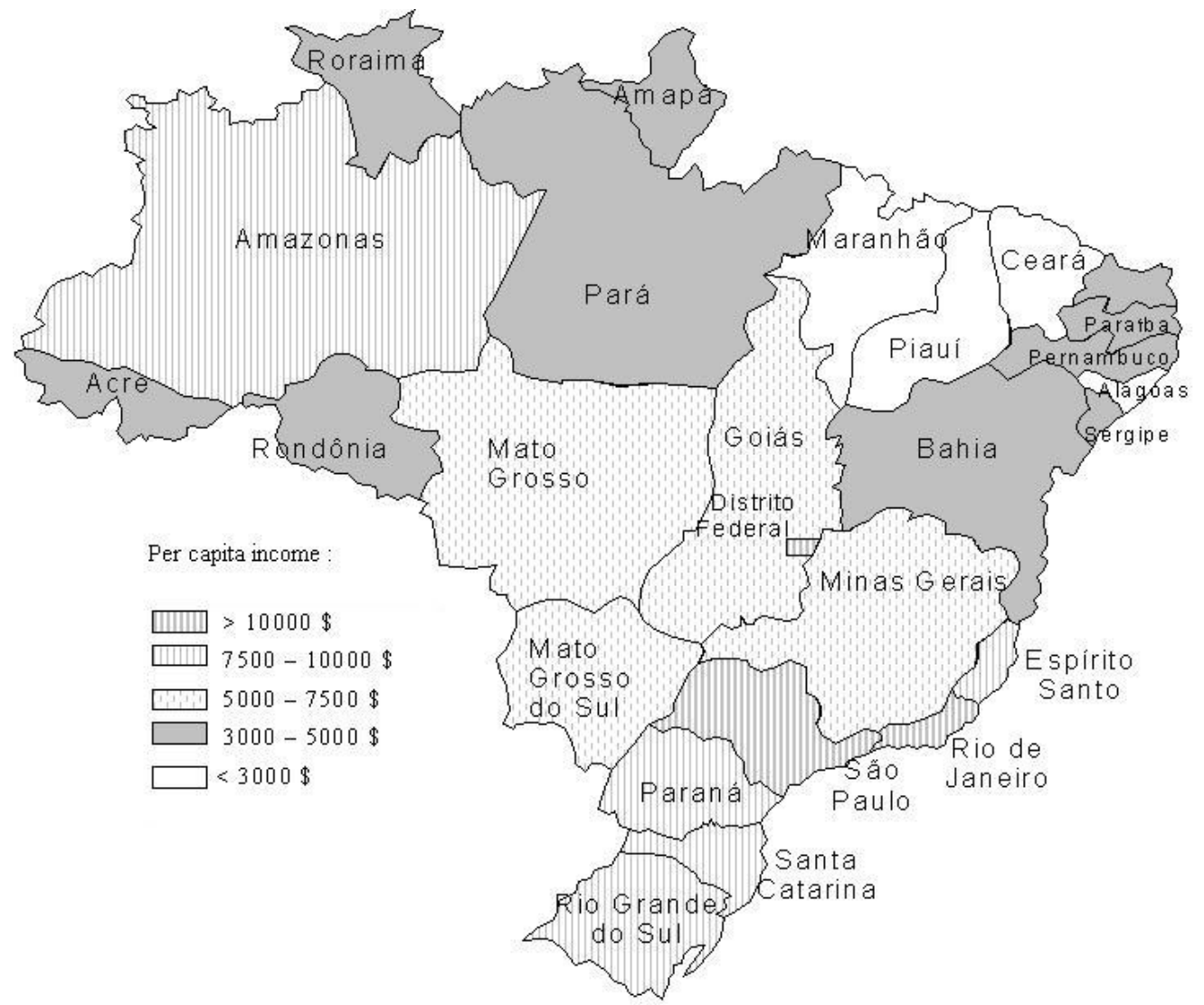

Source: Map by the authors. Per capita income is in PPP current USD. 
Figure A2 - Trade Openness by Brazilian state in 2000

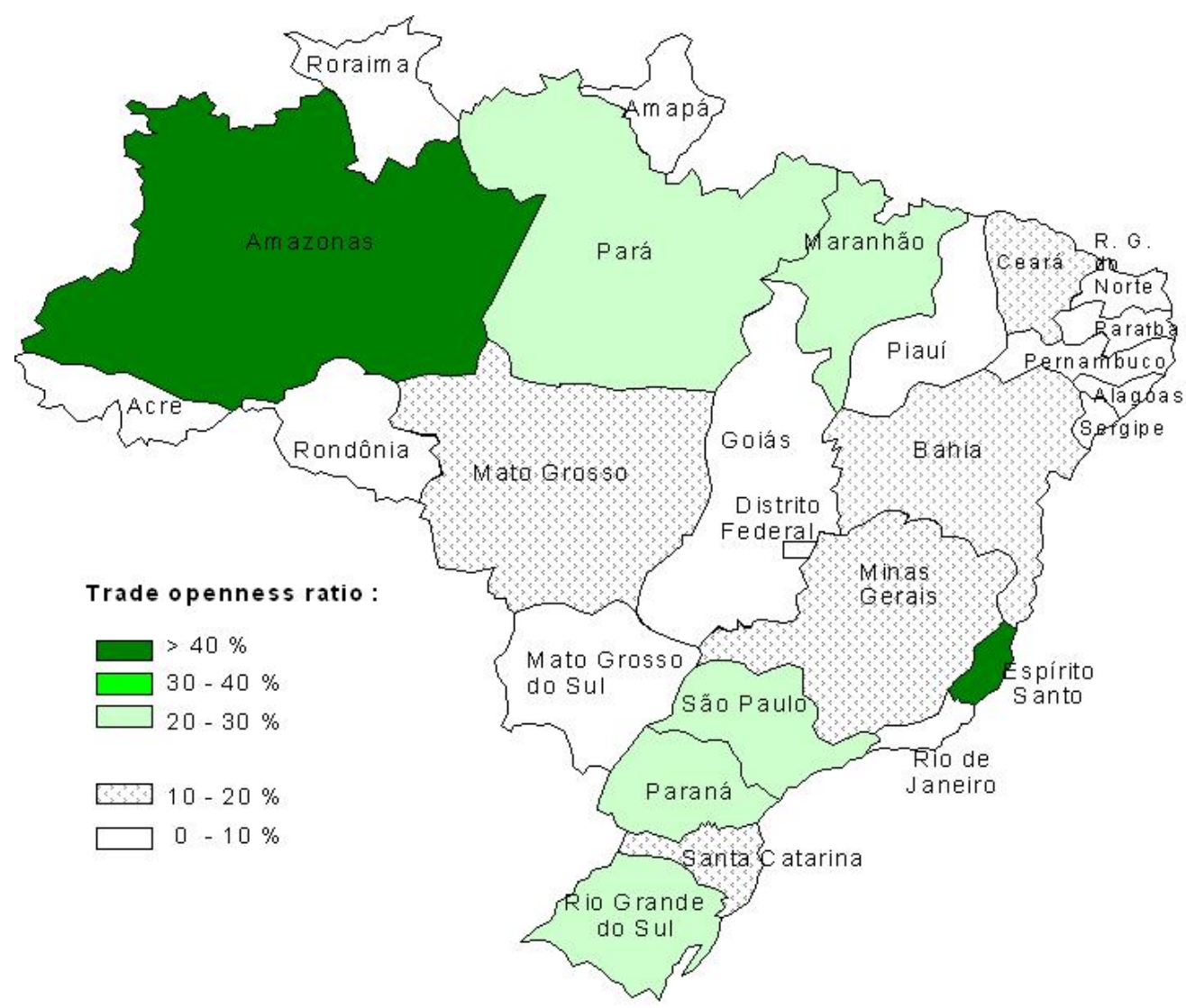

Source: Map by the authors. Trade openness is the volume of exports + imports in percentage of GDP.

Figure A3 - Trade Openness and GDP Per Capita of Brazilian States in 2002

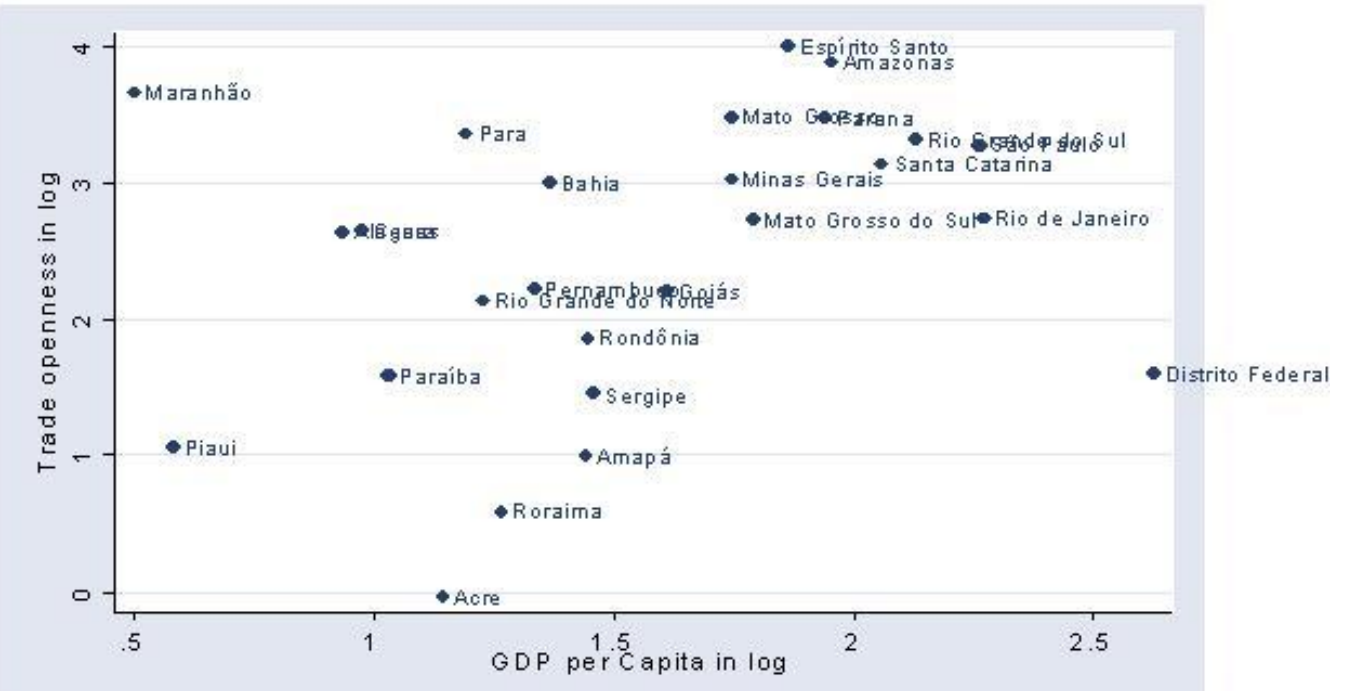

Note: Trade openness is exports + imports in percentage of GDP. Trade openness and GDP per capita are in $\log$. 